\title{
Effect of different concentrations of Ethylenediaminetetraacetic Acid (EDTA) on growth performance and physiological aspects of Nile Tilapia, Oreochromis niloticus Fingerlings.
}

\author{
Mohamed H. M. Ghanem ${ }^{1}$, Mohamed A. Ahmed ${ }^{2}$ and Ahmed M. Hassan ${ }^{1}$ \\ 1- Marine Biology branch, Zoology Dept., Faculty of Science, Al-Azhar \\ University, Cairo, Egypt
}

2- Fish diseases and management Dept., Faculty of veterinary Medicine, Cairo University, Egypt.

\section{ABSTRACT}

The present study deals with the effect of different concentrations of EDTA (0, $0.1 \& 0.3 \mathrm{~g}$ EDTA /L) on the growth in length, weight, survival rate, growth performance and physiological characters of the Nile tilapia, Oreochromis niloticus fingerlings reared in glass aquaria. The improvement of fish fingerlings development obtained by EDTA is dose-dependent. Fingerlings obtained from high concentration of EDTA (0.3 g EDTA /L) showed higher increase in length, weight and survival rate than those of low concentration $(0.1 \mathrm{~g}$ EDTA /L) and control. The total weight gain, average daily gain and specific growth rate of $O$. niloticus, fingerlings improved with the high concentration of EDTA compared with the low concentration and control. The best feed conversion ratio (1.82) was recorded in the fish fingerlings exposed to $0.3 \mathrm{~g} \mathrm{EDTA} / \mathrm{L}$ compared with the control (2.1) and fingerlings exposed to $0.1 \mathrm{~g}$ EDTA/L (2.44). Biochemical analysis indicated that, EDTA in high concentrations are useful additives for isolated or/ and reducing dangerous substances from different fish tissues and surrounding media, thus improved the physiological responses.

Keywords: EDTA; growth performance; physiological aspects; Oreochromis niloticus.

\section{INTRODUCTION}

A variety of chemicals and drugs are used in aquaculture for some purposes such as sediment and water management, enhancement of natural aquatic productivity, transport of live organisms, feed formulation, manipulation and enhancement of reproduction, growth promotion, health management, processing and adding value to the final product (Douet et al., 2009). Those include associated with structural materials, soil and water treatments, antibacterial agents, pesticides, feed additives, anesthetics and hormones (GESAMP, 1997).

EDTA has been used extensively in medicine as a chelating agent for removal of the toxic heavy metals. The disodium salt of EDTA is a common component in many eye drops and contact lens wetting and cleansing solutions. EDTA is also used in a number of personal care and hygiene products, such as shampoos, liquid soaps, creams, and lotions. Household disinfectants often contain EDTA, especially if fatty acid soaps are used in the disinfectant formulation. These soaps are sensitive to calcium and magnesium, and the chelating agent prevents the formation of hard-water soap curds (Hart, 1984). EDTA is a common sequestrant and antioxidant added to foods, body care, and household products. It binds trace minerals such as lead, copper, iron, cadmium and nickel that may be present in the product. When EDTA adds as an antioxidant, it prevents oxygen from causing color changes and rancidity (Ben-Best, 2009). EDTA has two advantages with respect to other compounds-its relative low 
biodegradability in groundwater systems (Nowack, 1996) and its strong complexing capacity with heavy metals (Kedziorek and Bourg, 2000).

Tilapia is an ideal candidate for warm water aquaculture. They spawn easily in captivity, use a wide variety of natural foods, as well as formulated feeds, tolerate poor water quality and grow rapidly at warm temperatures. These attributes, along with relatively low input costs have made tilapia widely cultured freshwater fish in tropical and subtropical countries (Biswas et al., 2005; El-Saidy and Gaber, 2005; Fasakin et al., 2005; Borgeson et al., 2006; Tahoun, 2007; Tsadik and Bar, 2007; AlAbsawy, 2010 and Khalaf Allah et al., 2013). In Egypt the Nile tilapia, Oreochromis niloticus aquaculture productin about 870938 tons which form $63.48 \%$ from our total aquaculture and natural production and put Egypt as a second bigger productive for Nile tilapia after China. The total production of tilapia fry from hatcheries or fish farms in 2012 attained 242.558 million fry of $O$. niloticus and $O$. aureus dominate the fry production (GAFRD, 2012 and FAO, 2014).

The effect of chelating agent (EDTA) as benefit in reduce lead and cadmium toxicity with improve the physiological and biochemical profiles of the fish and its impact on growth performance were investigated by few authors (Shalaby, 2007; Shalaby et al., 2011 and Tonsy and Abdel-Rahman, 2012). The previous studies, investigate the improvement of growth performance in the Nile tilapia, Oreochromis niloticus by exogenous treatments, L-thyroxine (T4) hormone (Khalil et al., 2011) and temperature (Hashem et al., 2012). However, there is a little information on the improvement of growth performance and physiological responses on the Nile tilapia by chelating agent, Ethylenediaminetetraacetic acid (EDTA). One of the difficulties in assessing the health state of natural fish population has been the paucity of reliable references in the normal conditions. Physiological and biochemical parameters reflects physical and chemical changes occurring in an organisms, therefore detailed information can be obtained on general metabolism and physiological status of the fish in different groups of age, habitat and different effects of anticoagulants, even in the same species (Kocabatmaz \& Ekingen, 1978 and Tavares-Dias \& Silva-Sandrim, 1998).

Therefore, the present study aimed to evaluate the effect of different concentrations of Ethylenediaminetetraacetic acid (EDTA) on growth performance and biochemical status of Nile tilapia, Oreochromis niloticus fingerlings. Such investigations may lead to a better understanding of some biological and physiological aspects.

\section{MATERIALS AND METHODS}

A total of 400 specimens of Oreochromis niloticus fingerlings, infected with black spot disease which caused by encysted metacercariae (Fig. 1) were obtained from El-Hadad Special Farm at Kafr El-Sheikh Governorate during October, 2013. Fish transported to Cairo in large plastic bags filled with oxygen, each containing approximately $20 \mathrm{~L}$ of fresh water. Duration of the journey was approximately three hours. Fish were acclimatized for one week in well aerated large glass tank; and fed daily on a commercial fish diet.

The experimental work was conducted using 9 separated tanks. Each one $(90 \times 55 X 30 \mathrm{~cm})$ filled with 80 liters fresh dechlorinated water. In each tank, 30 fish were kept randomly selected from the stock tank. Fish were exposed to $0.1 \mathrm{~g}$ EDTA $/ \mathrm{L}$ as treatment group 1, and $0.3 \mathrm{~g}$ EDTA /L as treatment group 2 and control. Each group including three tanks. 


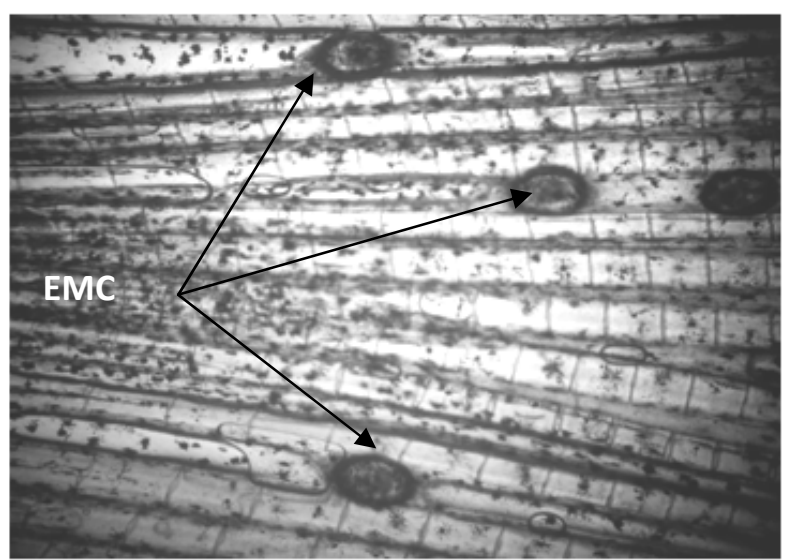

Fig. 1: Photomicrograph of caudal fin clip of Oreochromis niloticus fingerlings showing encysted metacercaria (EMC).

All tanks were provided with aeration and thermostastic heater, change of water was carried out and the aquaria were cleaned weekly and add one drop of $1 \%$ methylene blue for each tank. Fish in each aquarium were fed twice daily during six days per week by commercial diet containing 35\% protein. Fish were fed at a rate of 3 $\%$ of fresh body weight. The experiment was conducted for 5 weeks, length and weight of 15 randomly selected fish from each treatment were recorded weekly and their initial weights and survival rate were recorded.

\section{A-Biological Data:}

Growth in length, weight and survival rate estimation:

Length and weight of 15 randomly selected fish from each treatment were recorded weekly and their initial weights and survival rate were recorded.

\section{Measurement of growth performance:}

Total weight gain, average daily gain, specific growth rate, feed intake (FI) and feed conversion ratio in O. niloticus fry were determined according to Recker (1975) and Castell \& Tiews (1980) as following:

A-Total weight gain $(\mathrm{mg} /$ fish $)=\left(\mathrm{W}_{\mathrm{T}}-\mathrm{W}_{\mathrm{I}}\right)$.

Where: $\mathrm{W}_{\mathrm{T}}=$ final means weight of fish in grams.

$\mathrm{W}_{\mathrm{I}}=$ initial means weight of fish in grams.

B-Average daily gain (ADG) (g.fish/day) = total gain/ duration period.

C-Specific growth rate $(\mathrm{SGR}) \% /$ day $)=100 \times\left(\mathrm{Ln} \mathrm{W}_{\mathrm{T}^{-}} \mathrm{Ln} \mathrm{W}_{\mathrm{I}}\right) /$ duration period.

Where: $\mathrm{Ln}=$ Natural log.

D-Feed intake $(\mathrm{FI})=$ fish weight $\mathrm{x}$ feeding level $/ 100$

E-Feed conversion ratio $(\mathrm{FCR})=$ dry matter intake $(\mathrm{g}) /$ total gain $(\mathrm{g})$.

\section{B-Physiological studies:}

After dissection of fish, a known weight of the target organ (muscles collected from the fingerlings), are treated with 0.1 and 0.3 of EDTA were kept under freezing condition at $4 \mathrm{C}^{0}$ until the biochemical determination.

\section{- Tissue preparation:}

For determination of the total proteins, total lipids, total carbohydrates and enzymes activities including aspartate aminotransferase (ASAT) and alanine aminotransferase (ALAT), a known weight of each organ was homogenized in saline solution by using the electric homogenizer, for $2 \mathrm{~min}$. The homogenated specimens were centrifuged 4000 r.p.m. for $15 \mathrm{~min}$. at $2 \mathrm{C}^{0}$ in a refrigerator centrifuge. The supernatant solution was used directly or stored at $4 \mathrm{C}^{0}$ until the latter examinations.

\section{Determination of the total proteins:}

Total protein content in the muscles were determined according to the method of Doumas (1975) using a kit of Vitro Scient Company. 


\section{Determination of the total lipids:}

Total lipids content in muscles were determined according to the method of Kaplan (1984), using a kit of Reactivos GPL Company.

\section{Determination of the total carbohydrates:}

Total carbohydrates content in wet muscles were determined according to the method of Singh and Sinha (1977) as follows:

\section{Reagents:}

i) Anthrone reagent was prepared by addition of $72 \mathrm{ml}$ sulfuric acid to $28 \mathrm{ml}$ distilled water. While this mixture was still warm, $50 \mathrm{mg}$ of anthrone and $1 \mathrm{gm}$ of thiourea were added with a vigorous shaking, then it was used directly after slowly cooling at the room temperature then it stored at $8 \mathrm{C}^{0}$.

ii) Standard solution was prepared by addition of $50 \mathrm{mg}$ glucose to $100 \mathrm{ml}$ distilled water.

\section{- Procedure:}

- To determine the total carbohydrate content, $0.1 \mathrm{ml}$ of the aqueous samples was added into a test tube and diluted with $1 \mathrm{ml}$ distilled water then follow with $5 \mathrm{ml}$ freshly prepared anthrone reagent.

- The blank was prepared by adding $5 \mathrm{ml}$ of anthrone reagent to $1.1 \mathrm{ml}$ of the distilled water.

- The standard solution was prepared by adding $0.1 \mathrm{ml}$ of standard solution to $1 \mathrm{ml}$ distilled water and then add $5 \mathrm{ml}$ of the anthrone reagent.

All test tubes of blank, standard and samples were placed in a boiling water-bath for $10 \mathrm{~min}$. Then, it was leaved to cool for $15 \mathrm{~min}$. at the room temperature within a dark place. Reading of absorbance photometrically was recorded for the standard and the samples against blank at wavelength $620 \mathrm{~nm}$.

\section{Calculation:}

Total carbohydrates $(\mathrm{mg} / 100 \mathrm{ml})=\mathrm{A}_{\mathrm{s}} / \mathrm{A}_{\mathrm{st}} \mathrm{X} \mathrm{n}$

Where: $\quad \mathrm{A}_{\mathrm{s}}=$ Absorbance of the samples.

$\mathrm{A}_{\mathrm{st}}=$ Absorbance of the standard solution.

$\mathrm{n}=$ Concentration of standard solution $=0.05$ then, results were converted into $\mathrm{mg} / \mathrm{gm}$ tissue.

\section{Determination of ASAT and ALAT activities:}

ASAT and ALAT of wet muscles were determined according to the method of Reitman and Frankel (1957) by using a kit of Bioadwic Company.

\section{Statistical analysis:}

Results were expressed in tables as mean \pm S.D. Data were analyzed by using analysis of variance (ANOVA) according to Bailey (1981).

\section{RESULTS}

\section{I- Effect of EDTA on $O$. niloticus, fingerlings:}

Effect of different concentrations of EDTA on growth in length, growth in weight, survival rate and growth performance of the cichlid fish, $O$. niloticus fingerlings are given in Tables (1-4).

\section{1- Growth and survival rate:}

i) Growth in length:

The results in Table (1) show that, O. niloticus fingerlings exposed to EDTA $(0.1$ or $0.3 \mathrm{~g} / \mathrm{L})$ improved fingerlings growth. Moreover, treatment with high concentration of EDTA $(0.3 \mathrm{~g} / \mathrm{L})$ over the rearing period of 35 days gave a slight 
increase in length of fingerlings $(3.9 \pm 0.7 \mathrm{~cm})$ compared with the control and low concentration which have similar values during the period of study.

Table 1: Increments in standard length (Mean $\pm \mathrm{SD} \mathrm{cm}$ ) of $O$. niloticus fingerlings treated with EDTA.

\begin{tabular}{|c|c|c|c|}
\hline \multirow{2}{*}{$\begin{array}{c}\text { Exposure time } \\
\text { (Days) }\end{array}$} & Control & \multicolumn{2}{|c|}{ Treatments } \\
\cline { 3 - 4 } & & $0.1 \mathrm{~g}$ EDTA/L & $0.3 \mathrm{~g}$ EDTA/L \\
\hline 0 & $3.2 \pm 0.4$ & $3.2 \pm 0.4$ & $3.2 \pm 0.4$ \\
\hline 7 & $3.5 \pm 0.4$ & $3.5 \pm 0.4$ & $3.6 \pm 0.4$ \\
\hline 14 & $3.5 \pm 0.5$ & $3.5 \pm 0.5$ & $3.6 \pm 0.5$ \\
\hline 21 & $3.6 \pm 0.6$ & $3.6 \pm 0.6$ & $3.7 \pm 0.6$ \\
\hline 28 & $3.6 \pm 0.6$ & $3.6 \pm 0.6$ & $3.7 \pm 0.6$ \\
\hline 35 & $3.8 \pm 0.7$ & $3.8 \pm 0.7$ & $3.9 \pm 0.7$ \\
\hline
\end{tabular}

\section{ii) Growth in weight:}

Data in Table (2) indicate regular increase in total body weight of $O$. niloticus fingerlings treated with EDTA compared with control. It is obvious that a slight increase is evident at high concentration during the period of experiment. But the reverse was show at low concentration, recorded the lowest value of increments in total body weight compared with control.

Table 2: Increments in total weight (Mean \pm SD gm), of $O$. niloticus fingerlings treated with EDTA.

\begin{tabular}{|c|c|c|c|}
\hline \multirow{2}{*}{$\begin{array}{c}\text { Exposure time } \\
\text { (Days) }\end{array}$} & \multirow{2}{*}{ Control } & \multicolumn{2}{|c|}{ Treatments } \\
\cline { 3 - 4 } & & $0.1 \mathrm{~g}$ EDTA/L & $0.3 \mathrm{~g}$ EDTA/L \\
\hline 0 & $1.143 \pm 0.3$ & $1.143 \pm 0.3$ & $1.143 \pm 0.3$ \\
\hline 7 & $1.250 \pm 0.3$ & $1.248 \pm 0.3$ & $1.289 \pm 0.3$ \\
\hline 14 & $1.356 \pm 0.4$ & $1.352 \pm 0.4$ & $1.437 \pm 0.4$ \\
\hline 21 & $1.462 \pm 0.5$ & $1.457 \pm 0.5$ & $1.582 \pm 0.5$ \\
\hline 28 & $1.674 \pm 0.6$ & $1.641 \pm 0.6$ & $1.771 \pm 0.6$ \\
\hline 35 & $1.842 \pm 0.7$ & $1.768 \pm 0.7$ & $1.931 \pm 0.7$ \\
\hline
\end{tabular}

\section{iii) Survival rate:}

The present results (Table, 3) indicate that, O. niloticus fingerlings exposed to EDTA $(0.1$ or $0.3 \mathrm{~g} / \mathrm{L})$ improved survival rate of fingerlings than those of control. The treatment with high concentration of EDTA $(0.3 \mathrm{~g} / \mathrm{L})$ over the rearing period $(35$ days) gave higher increase in survival rate of fingerlings $(90.9 \%)$ declined to $85.1 \%$ at $0.1 \mathrm{~g} / \mathrm{L}$ compared with $60.6 \%$ at control. It was also noted that, the external mortality signs of control showing erosion of caudal fin, exophthalmos and abdomen swelling (Figs. 2\&3). While, the external mortality signs of treated fish exposed to EDTA showing enlargement in gills associated with open mouth.

Table 3: Survival rate (\%) for O. niloticus fingerlings treated with EDTA.

\begin{tabular}{|c|c|c|c|}
\hline \multirow{2}{*}{$\begin{array}{c}\text { Exposure time } \\
\text { (Days) }\end{array}$} & \multirow{2}{*}{ Control } & \multicolumn{2}{|c|}{ Treatments } \\
\cline { 3 - 4 } & & $0.1 \mathrm{~g}$ EDTA/L & $0.3 \mathrm{~g}$ EDTA/L \\
\hline 0 & 100 & 100 & 100 \\
\hline 7 & 93.9 & 97.9 & 97 \\
\hline 14 & 81.8 & 95.7 & 97 \\
\hline 21 & 77.3 & 93.6 & 97 \\
\hline 28 & 69.7 & 91.5 & 92.4 \\
\hline 35 & 60.6 & 85.1 & 90.9 \\
\hline
\end{tabular}

\section{iv) Growth performance:}

Data in Table (4) show, body weight, total weight gain, average daily gain (ADG g.fish/day), specific growth rate (SGR\%/day), feed intake (FI gm/fish) and feed conversion ratio (FCR) for O. niloticus treated with EDTA. 
The present data show that, the total weight gain of $O$. niloticus, fingerlings improved in general with the increasing concentration of EDTA up to $0.3 \mathrm{~g}$ EDTA/L compared with the control and low dose. The highest value of total weight gain (0.788) was detected in the fish exposed to $0.3 \mathrm{~g}$ EDTA/L. The same pattern was observed with average daily gain and specific growth rate (Table, 4).

The specific growth rate (S. G. R.) for the fish exposed to $0.3 \mathrm{~g}$ EDTA/L (1.50) is higher than the value (1.25) for the fish exposed to $0.1 \mathrm{~g}$ EDTA/L compared with the control (1.36). The best feed conversion ratio (1.82) was recorded in the fish exposed to $0.3 \mathrm{~g}$ EDTA/L compared with the control (Table, 4$)$.

Table 4: Growth performance of $O$. niloticus, treated with different concentrations of EDTA.

\begin{tabular}{|c|c|c|c|}
\hline Item & Control & $\begin{array}{c}0.1 \mathrm{~g} \\
\text { EDTA } / \mathrm{L}\end{array}$ & $\begin{array}{c}0.3 \mathrm{~g} \\
\text { EDTA } / \mathrm{L}\end{array}$ \\
\hline Initial live weight (g/fish) & $1.143 \pm 0.3$ & $1.143 \pm 0.3$ & $1.143 \pm 0.3$ \\
\hline Final live weight (g/fish) & $1.842 \pm 0.7$ & $1.768 \pm 0.7$ & $1.931 \pm 0.7$ \\
\hline Weight gain (g/fish) & 0.699 & 0.625 & 0.788 \\
\hline Average daily gain (g.day/fish) & 0.020 & 0.018 & 0.023 \\
\hline Specific growth rate (\%day) & 1.36 & 1.25 & 1.50 \\
\hline Feed intake (FI) (g/fish) & 1.468 & 1.523 & 1.434 \\
\hline Feed conversion ratio (FCR) & 2.1 & 2.44 & 1.82 \\
\hline
\end{tabular}

\section{II- Physiological studies:}

Biochemical analysis in the muscle of fingerling stage of $O$. niloticus reared in glass aquaria for 35 days are showing in Table (5) and are graphically represented in Figs. (4 -8).

Table 5: Biochemical analysis in the fingerling stage muscles of Oreochromis niloticus, exposed to the different concentrations of EDTA.

\begin{tabular}{|c|c|c|c|c|c|}
\hline $\begin{array}{c}\text { Concentrations } \\
\text { (g/L EDTA) }\end{array}$ & $\begin{array}{c}\text { Total Proteins } \\
(\mathrm{mg} / \mathrm{g} \text { wet wt. })\end{array}$ & $\begin{array}{c}\text { Total Lipids } \\
(\mathrm{mg} / \mathrm{g} \text { wet wt. })\end{array}$ & $\begin{array}{c}\text { Total } \\
\text { Carbohydrates } \\
(\mathrm{mg} / \mathrm{g} \text { wet wt. }\end{array}$ & $\begin{array}{c}\text { ASAT } \\
(\mathrm{U} / \mathrm{g} \text { wet wt. })\end{array}$ & $\begin{array}{c}\text { ALAT } \\
(\mathrm{U} / \mathrm{g} \text { wet wt. })\end{array}$ \\
\hline Control & $211.67 \pm 7.02$ & $70.00 \pm 2.00$ & $7.47 \pm 0.28$ & $6.00 \pm 0.20$ & $0.90 \pm 0.10$ \\
\hline $0.1 \mathrm{~g} / \mathrm{L}$ & $262.33 \pm 12.42$ & $65.17 \pm 2.75$ & $4.10 \pm 0.35$ & $5.63 \pm 0.15$ & $0.67 \pm 0.0 .6$ \\
\hline $0.3 \mathrm{~g} / \mathrm{L}$ & $297.33 \pm 8.74$ & $58.97 \pm 2.59$ & $3.57 \pm 0.51$ & $5.37 \pm 0.15$ & $0.53 \pm 0.06$ \\
\hline
\end{tabular}

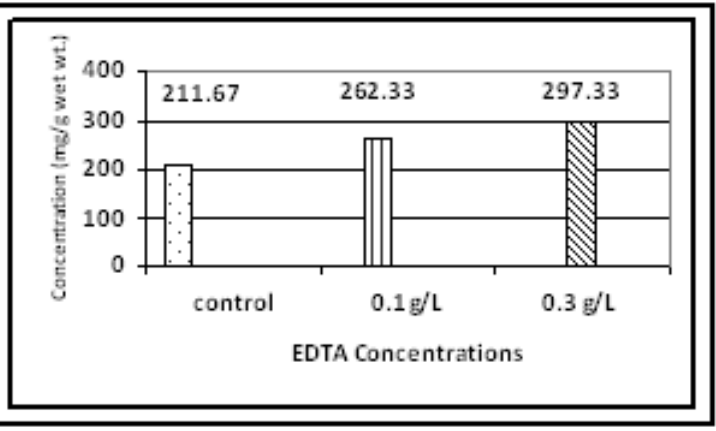

Fig. 4: Changes of total proteins in the muscles of treated Oreochromis niloticus fingerling with different concentrations of EDTA.

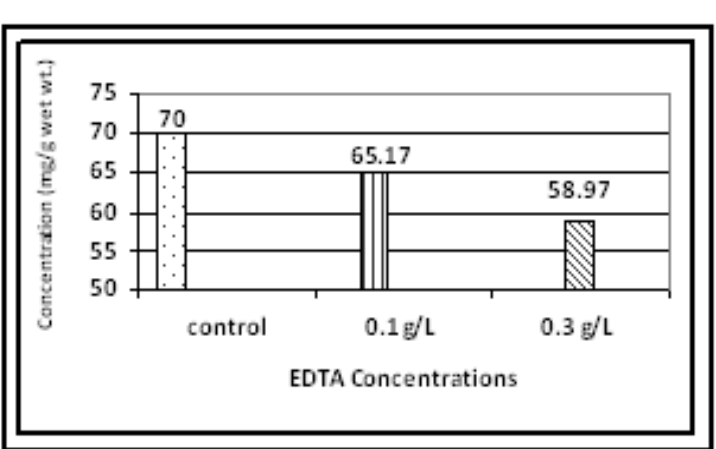

Fig. 5: Changes of total lipids in the muscles of treated Oreochromis niloticus fingerling with different concentrations of EDTA. 


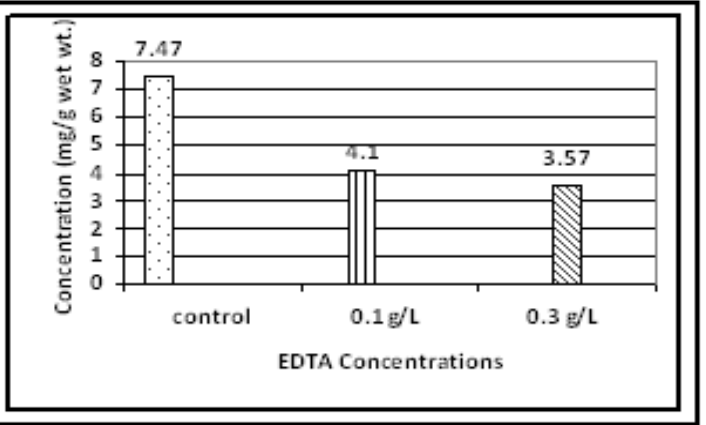

Fig. 6: Changes of total carbohydrates in the muscles of treated Oreochromis niloticus fingerling with different concentrations of EDTA.

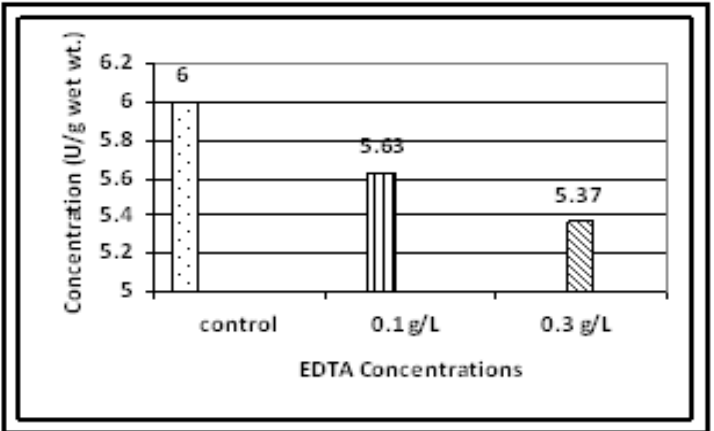

Fig. 7: Changes of ASAT activity in the muscles of treated Oreochromis niloticus fingerling with different concentrations of EDTA.

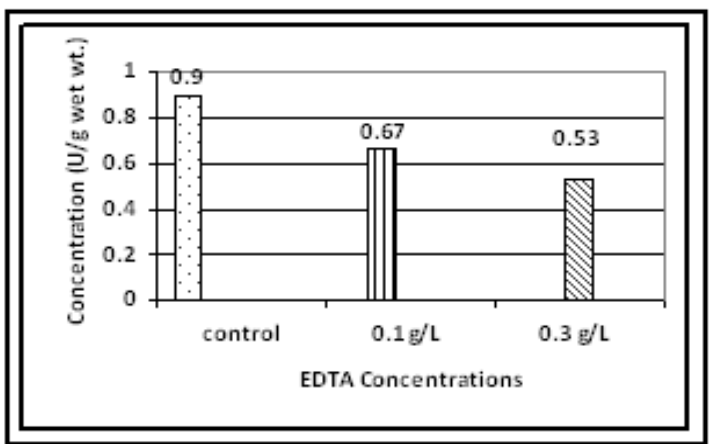

Fig. (8): Changes of ALAT activity in the muscles of treated Oreochromis niloticus fingerling with different concentrations of EDTA.

The present results showed that, an addition of EDTA to aquaria contain fingerling stage of $O$. niloticus affects growth and biochemical parameters due to enhancement in metabolic parameters and enzymes activities at different concentrations compared with control samples.

Table (5) and Figure (4) show a significant difference of total proteins in the muscles of $O$. niloticus fingerlings reared in aquaria treated with different concentrations $(0.1 \mathrm{~g} / \mathrm{L}$ and $0.3 \mathrm{~g} / \mathrm{L})$ compared with control samples; being $262.33 \pm 12.42 \mathrm{mg} / \mathrm{g}$ wet wt. in the lowest dose and $297.33 \pm 8.74 \mathrm{mg} / \mathrm{g}$ wet wt. in the highest one compared with $211.67 \pm 7.02 \mathrm{mg} / \mathrm{g}$ wet wt. for control. Anova $(\mathrm{P}<0.05)$ indicated that, a highly significant differences were obtained at the different concentrations of EDTA.

However, a slightly decreases was observed in the concentration of total lipids in muscles of fingerling stage, $O$. niloticus at low concentration of EDTA treatments $(0.1 \mathrm{~g} / \mathrm{L})$ and reached its lowest value at high concentration of treatments $(0.3 \mathrm{~g} / \mathrm{L})$ compared with control; being $65.17 \pm 2.75 \mathrm{mg} / \mathrm{g}$ wet wt. for minimal dose and $58.97 \pm 2.59 \mathrm{mg} / \mathrm{g}$ wet $\mathrm{wt}$. for the maximal one compared with $70.00 \pm 2.00 \mathrm{mg} / \mathrm{g}$ wet wt. for control samples (Table, 5 and Figure, 5). Statistically, $(\mathrm{P}<0.05)$ showed highly significant difference at the high concentration of EDTA.

Results are shown in Table (5) and Figure (6) attained a reverse decreasing in total carbohydrates in the muscles of $O$. niloticus fingerlings exposed to EDTA with increasing in dose concentration compared with control. The minimum value of total carbohydrates was recorded in the samples exposed to $0.3 \mathrm{~g} / \mathrm{L}(3.57 \pm 0.51 \mathrm{mg} / \mathrm{g}$ wet wt.). It showed a slightly increase at the samples treated with $0.1 \mathrm{~g} / \mathrm{L}(4.1 \pm 0.35 \mathrm{mg} / \mathrm{g}$ 
wet wt.) but the highest value was recorded for control group $(7.47 \pm 0.28 \mathrm{mg} / \mathrm{g}$ wet wt.). Analysis of variance $(\mathrm{P}<0.05)$ exhibited that, a highly significant differences were recorded at different concentrations.

The present study exhibited that, the depletion of aspartate aminotransferase (ASAT) in the muscles of $O$. niloticus fingerlings was observed with increasing the dose of EDTA compared with control; being $5.63 \pm 0.15 \mathrm{U} / \mathrm{g}$ wet wt. at low concentration $(0.1 \mathrm{~g} / \mathrm{L})$ and $5.37 \pm 0.15 \mathrm{U} / \mathrm{g}$ wet wt. at high concentration $(0.3 \mathrm{~g} / \mathrm{L})$ compared with $6.00 \pm 0.20 \mathrm{U} / \mathrm{g}$ wet wt. for the control samples (Table, 5 and Figure, 7). Anova $(\mathrm{P}<0.05)$ indicate a significant difference at high concentration of EDTA.

Alanine aminotransferase activity (ALAT) in the muscles of fingerling stage of $O$. niloticus exposed to different concentrations of EDTA showed acute depletion with increasing in concentration of the dose compared with control samples; being $0.53 \pm 0.06 \mathrm{U} / \mathrm{g}$ wet wt. at the high concentration $(0.3 \mathrm{~g} / \mathrm{L})$ and $0.67 \pm 0.06 \mathrm{U} / \mathrm{g}$ wet wt. at the low concentration $(0.1 \mathrm{~g} / \mathrm{L})$ compared with $0.9 \pm 0.10 \mathrm{U} / \mathrm{g}$ wet wt. in the samples of control (Table, 5 and Figure, 8). Statistical analysis $(\mathrm{P}<0.05)$ show a significant differences at the different concentrations.

\section{DISCUSSION}

This study aims to evaluate the effect of different concentrations of Ethylenediaminetetraacetic acid on growth parameters, growth performance and survival rate of $O$. niloticus fingerlings. Tilapians are considered as the best species for culture, because of their high tolerance to adverse environmental conditions, ease of reproduction, their fast growth and potential for domestication (EL-Sayed, 1999).

In the present study, the treatment with $0.3 \mathrm{~g}$ EDTA / $\mathrm{L}$ accelerated fingerlings growth, since a higher increase in growth in length, growth in weight of fingerlings occurred during the experimental period. Treated fish fingerlings gave also a higher survival rate than that of control. Similar reports showed that, EDTA improves survival rates and accelerate growth and development in teleost fish (Shalaby, 2007; Shalaby et al., 2011; El-Banna and Atallah, 2009 and Tonsy \& Abdel-Rahman, 2012).

The improvement of fish fingerlings development obtained by EDTA at the present study is dose-dependent. Fingerlings obtained from high concentration of EDTA (0.3 g EDTA /L) showed higher increase in length, weight and survival rate than those of low concentration of EDTA $(0.1 \mathrm{~g}$ EDTA $/ \mathrm{L})$. No abnormalities were observed in fish fingerlings from treated with EDTA. However, the data suggest that a concentration of $0.3 \mathrm{~g}$ EDTA / $\mathrm{L}$ is appropriate for accelerating growth and improving survival during the experimental period. Similar observations were obtained by Shalaby (2007); Shalaby et al. (2011); El-Banna and Atallah (2009) and Tonsy \& Abdel-Rahman (2012).

On the other point of view, Kasetsart (2011) studied the effect of different concentrations of EDTA on the development of oyster, Crassostrea belcheri and mentioned that, no significant differences in mean percentages of embryos that developed into normal D-larvae were found among untreated and treated units at $\mathrm{Na}_{2}-$ EDTA concentrations ranging from 5 to $20 \mathrm{ppm}(\mathrm{P}>0.05)$. Non-significant differences were found among the mean percentages of fertilized eggs that developed into normal trochophore larvae in untreated seawater and seawater pre-treated with $\mathrm{Na}_{2}$-EDTA and conditioned from 0 to $48 \mathrm{hr}(\mathrm{P}>0.05)$.

The growth promoters improve the immunity, productivity and economic efficiency of fish via its improvement body weight of the fish (Carnevali et al., 
2006), weight gain (Venkat et al., 2004), feed conversion ratio and efficiency (Abdel-Hamid and Mohamed, 2008).

In the present study, the best feed conversion ratio was recorded in fish fingerlings (1.82) when the fish treated by $0.3 \mathrm{~g}$ EDTA /L compared to control (2.1). This result was higher than that recorded in the same species in other farms. El-Shebly (1991\& 1998) recorded food conversion of 1.8 in Serow Fish-Farm and 1.21 in fresh water fish farm at Manzalah Lake. Chelators such as EDTA have been reported to possess antibacterial activity because of the ability of these chelating agents to disrupt bacterial cell membranes by removing essential divalent cations required to link lipopolysaccharide molecules in the outer membrane (Vaara, 1992). Furthermore, strong chelates may inhibit microbial metabolism by binding trace mineral required for cellular reproduction, growth and survival (Boziaris and Adams, 1999).

Culture assays indicate that, both EDTA and EDTA-chelated trace metals enhance the growth of phytoplankton in sea water (Johnston, 1964). Two mechanisms have been proposed for the enhancement of algal growth by chelating agents such as EDTA. Johnston (1964) suggested that, EDTA increases the solubility and thus the availability of trace metals that are necessary for growth. However, an alternative hypothesis is that chelating agents reduce the availability of harm metals to phytoplankton by lowering the concentration of harm free metal ions (Sunda and Guillard, 1976). In this hypothesis, enhanced algal growth in the presence of EDTA is explained by reduced inhibition by toxic metals which are present in sea water (Davey et al., 1973; Sunda and Guillard, 1976 and Ragan et al., 1980).

The present study revealed that, the average values of final body weight, total weight gain and average daily gain (ADG $\mathrm{g} /$ fish/day) increase in the fish fingerlings when the fish treated by $0.3 \mathrm{~g}$ EDTA /L compared to control. Results came in close agreement with those obtained by Shalaby (2007); Shalaby et al. (2011) and El-Banna \& Atallah (2009). Tonsy \& Abdel-Rahman (2012) mentioned that, growth performance in $O$. niloticus was improved due to EDTA application and the effects were more pronounced at $1.5 \%$ EDTA/ $\mathrm{kg}$ diet, which are considered as the optimum dose that improve the health status and growth parameters of fish.

The present results showed that, an addition of EDTA to aquaria contains fingerlings of $O$. niloticus affects on growth and biochemical parameters due to enhancement in metabolic parameters and enzymes activities at different concentration compared with control samples.

A significant increase of total proteins was observed in the muscles of $O$. niloticus fingerlings reared in aquaria treated with different concentrations of EDTA $(0.1 \mathrm{~g} / \mathrm{L}$ and $0.3 \mathrm{~g} / \mathrm{L})$ compared with control samples. This increasing may be attributed to the additional EDTA to the media isolate the poisonous substances from the different tissues. These findings which agree with those of Morel et al. (1987); Kargin (1996); Abdel-Rahman et al. (2009); Rengaswamy et al. (2009) and Tonsy \& Abdel-Rahman (2012). On the other hand, Shalaby (2003) reported a significant decreasing in these values with exposure to Cd only or with low levels of EDTA at 45 days and attributed his findings to great demands and cellular damage that occurred in the tissues of $\mathrm{Cd}$ - toxicated fish as $\mathrm{Cd}$ toxicity may cause protein breakdown.

However, total lipids in the muscles of fingerling stage, O. niloticus exhibited a slightly decrease with increasing concentration of EDTA compared with control. This may be due to EDTA application and its effects was more pronounced at $0.3 \mathrm{~g} / \mathrm{L}$ EDTA, which are considered as the optimum dose that improve the healthy status and growth parameters of the fish in this experiment. Similar observations were reported by James \& Sampath (1999) and Nicula et al. (2011). They mentioned that, all the 
tested biochemical parameters and growth performance were improved due to EDTA application and their effects were more evident at $1.5 \%$ EDTA/ $\mathrm{kg}$ diet. But differ with Shalaby (2007) on Oreochromis niloticus and Shalaby et al. (2011) on Clarias gariepinus, who indicated that, the addition of EDTA lowered total lipids concentration in the fish, exposed to cadmium toxicity to be similar to that of the control fish.

In the present results, a reverse decreasing in total carbohydrate in the muscles of $O$. niloticus fingerlings exposed to EDTA with increasing in the dose concentration were less than that showed in the control samples. This may be attributed to the depletion in tissues glycogen could have resulted because of its utilization for supplying the energy to the fish under stressed conditions. Similar observations were obtained by Dheer et al. (1986); Al-Akel et al. (1988) and Ghanem (2006) whom confirmed the fact that, all stress conditions invariably lead to retardation of growth and alter the physiological mechanism. If the stressed condition continuous, long enough mortality ensues.

Also, the results exhibited the depletion of aspartate aminotransferase and alanine aminotransferase (ASAT \& ALAT) activities in the muscles of $O$. niloticus fingerlings were observed with increasing the dose of EDTA compared with control. The significant changes in activities of different enzymes (ASAT \& ALAT) may be due to the tissues impairment caused by stress conditions. Similar observations were obtained by James et al. (1991); Svoboda (2001) and Shalaby et al. (2011) and differ with Yamawaki et al. (1986) and Shalaby (1997) who stated that, the increase of ASAT and ALAT may be attributed to the hepato-cellular damage or cellular degradation by these heavy metals, perhaps in liver, heart or muscle. However, the decrease of ASAT and ALAT activities in the muscles may be attributed to a number of reasons such as leakage from liver and muscles into the blood, actual liver and muscles enzymes inhibition by the effect of toxicant, disturbance in Kreb's cycle and damage of liver and kidney cells that affect the membranes permeability which in turn liberate the enzymes to extra-cellular fluid and blood (Abou El-Ella, 1996; Salah ElDeen et al., 1996\& 2000; Zaghloul, 1997; Abbas, 1998 and Ghanem, 2006\& 2011 ).

\section{CONCLUSION}

The growth performance of Nile tilapia, Oreochromis niloticus fingerlings are good pattern in the fingerlings treated by $0.3 \mathrm{~g}$ EDTA $/ \mathrm{L}$. These observations suggest that, the exogenous treatment $(0.3 \mathrm{~g}$ EDTA $/ \mathrm{L}$. $)$ may have practical utility in the fish culture and improve the physiological status.

\section{REFERENCES}

Abbas, H.H. (1998). Toxicological effects of copper and lead on some physiological aspects in two fish species, blue Tilapia, Oreochromis aureus and African catfish, Clarias gariepinus. Ph.D. Thesis, fac. Sci. Cairo Univ. Egypt.

Abdel-Hamid, E. and Mohamed, K. A. (2008). Effect of using probiotic as growth promoters in commercial diets for monosexnile tilapia, Oreochromis niloticus fingerlings. $8^{\text {th }}$ International Symposium on Tilapia in Aquaculture, 2008. Cairo International Convention Center (CICC). Egypt. 12-14/10/2008.

Abdel-Rahman, A. S.; Hossny, A. M. and El-khawas, K. M. (2009). Trials for treatment of Procambarus clarkii from hazardous pollutants and Assessment of hygienic states for consumption. Egypt. J. Aquat. Biol. \& Fish., 13(4):161-177. 
Abou El-Ella, S. M. (1996). Studies on the toxicity and bioconcentration of cadmium on grass carp, Ctenopharyngodon idella. M.Sc. Thesis, Fac. Sci. Helwan Univ. Egypt.

Al-Absawy, A. N. M. (2010). Nutritional requirements for Nile tilapia, Oreochromis niloticus, cultivated in El-Max research station with special references to their growth and feeding habits. M. Sc. Thesis, Zool. Depart. Fac. Sci. Al-Azahra University, Cairo, $317 \mathrm{pp}$.

Al-Akel, A. S.; Shamsi, M. J. K.; Al-Kahem, H. F.; Chaudhary, M. A. and Ahmed, Z. (1988). Effect of cadmium on the cichlid fish, Oreochromis niloticus: behavioural and physiological responses. J.Univ.Kuwait (Sci)., 15(2): 341-346.

Bailey, N. T. J. (1981). Statistical methods in biology. $2^{\text {nd }}$ Ed. (Biological Science Texts): 216pp.

Ben-Best, F. (2009). \EDTA\EDTA_ChemistrylCHELATION THERAPY WITH EDTA V.Imp.mht.

Biswas, A. K.; Morita, T.; Yoshizaki, G.; Maita, M. and Takeuchi, T. (2005). Control of reproduction in Nile tilapia, Oreochromis niloticus (L.) by photoperiod manipulation. Aquacult., 243:229-239.

Borgeson, T. L.; Racz, V.; Wilkie, D. C.; White, L. J. and Drew, M. D. (2006). Effect of replacing fishmeal and oil with simple or complex mixtures of vegetable ingredients in diets fed to Nile Tilapia, Oreochromis niloticus. Aquacult. Nutr., 12: 141-149.

Boziaris, I.S. and M.R. Adams (1999). Effect of chelators and nisin produced in situ on inhibition and inactivation of gram-negatives. Int. J. Food Microbiol., 53: 105-113.

Carnevali, O.; Vivo, L.; Sulpizio,R.; Gioacchini, G.; Olivotto, I.; Silvi, S. And Cresci, A. (2006). Growth improvement by probiotic in European seabass juveniles (Dicentrarchus labrax, L.), with particular attention to IGF-1, myostation and cortisolgene expression. Aquacult., 258 (430 - 438).

Castell, J. D. and Tiews, K. (1980). Report of the EIFAC, IUNS and ICES Working Group on the Standardization of Methodology in Fish Research. Hamburg, FRG, Germany, 21-23 March. IFAC Tech. Pap. (3) 24.

Davey, E. W.; Morgan, M. J. and Erickson, S. J. (1973). A biological measurement of the copper complexation capacity of seawater. Limnol. and Oceanog., 18: 993-997.

Dheer, J. M. S.; Dheer. T. R. and Mahajan, C. L. (1986). Haematological and haematopoietic response to sodium chloride stress in a freshwater airbreathing fish. Channa punctatus, Bloch. J. Fish Biol., 28:119-128.

Douet, D. G.; Le-Bris, H. and Girau, E. (2009). Environmental aspects of drug and chemical use in aquaculture: an overview, Options Mediterranean's, 86, 105-12

Doumas, B. T. (1975). Colourimetric determination of total protein in serum or plasma. Clin. Chem., 21(8): 1159-1166.

El-Banna, S. A. and Atallah, S. T. (2009). Study the role of feed additives in prevention of fish diseases incidence in Oreochromis niloticus and common carp fish and its economic importance. J. Arabian Aquacult. Soci., 4 (2):121- 139.

EI-Saidy, D. M. S. and Gaber, M. M. A. (2005). Effect of dietary protein levels and feeding rates on growth performance, production traits and body composition of Nile Tilapia, (Oreochromis niloticus) (L.) cultured in concrete tanks. Aquacult. Res., 36 (2): 163- 171.

EL- Sayed, A. F. M. (1999). Alternative dietary protein sources for farmed Tilapia (Oreochromis sp). Aquacult., 179: 149-168. 
El-Shebly, A. A. (1991). Effect of fertilizers on rearing of fish in Serow Fish-Farm. M.Sc. Thesis, Fac. Sci. Mansoura Univ., 222pp.

El-Shebly, A. A. (1998). Studies on Growth and production of Oreochromis niloticus in semi-intensive fish culture. J. Egypt. Ger. Soc. Zool., vol. 27(B): 69-80.

F. A. O. (2014). Fishery Statistics 2012, Capture Production, FAO, Rome.

Fasakin, E. A.; Serwata, R. D. and Davies. S. J. (2005). Comparative utilization of rendered animal derived products with or without composite mixture of soybean meal in hybrid Tilapia (Oreochromis niloticus X Oreochromis mossambicus) diets. Aquacult., 249 (1-4): 329-338.

G.A.F.R.D. (2012). General Authority for Fish Resources Development. Fishery Statistic. Egyptian Ministry of Aquaculture.

G.E.S.A.M.P. (1997). (group of experts on the scientific aspects of marine environmental protection): Towards safe and effective use of chemicals in coastal aquacult., $65, \mathrm{pp} 37$.

Ghanem, M. H. M. (2006). Ecological, physiological and histopathological studies on the grey mullet, Mugil cephalus, at different Egyptian lakes. M.Sc. Thesis, Faculty of Science, Al-Azhar Univ., Cairo,456 pp

Ghanem, M. H. M. (2011). Seasonal variations of total proteins, lipids and carbohydrates in cultivated, brackish and salt water fishes with special references to their nutrient values. .Ph. D. Thesis, Fac. Sci. Al-Azhar Univ., Cairo, 395pp.

Hart, J. R. (1984). EDTA-type chelating agents in everyday consumer products: some medicinal and personal care products. J. of chem. edu., 61(12):1060-1061.

Hashem, A. M.; Khalil1, N. A. El-Gohary, N. M. (2012). Effect of rearing temperature on larval growth and the digestive system development in the Nile tilapia, Oreochromis niloticus. J. Egypt. Ger. Soc. Zool., vol. 64(C): 49-76.

James, R. and Sampath, K (1999). Effect of the ion- exchanging agent, Zeolite, on reduction of cadmium toxicity: an experimental study on growth and elemental uptake in Heteropneustes fossilis (Bloch). J. Aqua. Trop., 14 (1): 65- 74.

James, R.; Sivakumar, V.; Sampath, K. and Rajendran, P. (1991). Individual and combined effects of zinc; cadmium and copper on growth of Oreochromis mossambicus. Indian. J. Fish., 38: 198- 200.

Johnston, R. (1964). Sea water, the natural medium of phytoplankton. ii. Trace metals and chelation, and general discussion. J. Marine Biol. Associ. of the U.K. 44:87-109.

Kaplan, A. (1984). lipids clin.chem the c.v. mosby co. St Louis Tornto. Princeton; 918-919

Kargin, F. (1996). Elimination of cadmium from cd-contaminated tilapia zilli in media containing EDTA and freshwater: changes in protein levels. Bull. Environ. Contam. Toxicol., 57:211-216

Kasetsart, J. (2011). Na2-EDTA effects on the development of oyster, Crassostrea belcheri (Sowerby) Larvae. Nat. Sci., 45: 1058 - 1063.

Kedziorek, M. A. M and Bourg, A. S. M (2000). Solubilization of lead and cadmium during the percolation of EDTA through a soil polluted by smelting activites. Contam. Hydrol., 40: 381-392.

Khalaf-Allah, H. M. M.; Abdel-Ghany, M. O. and Abu-Zaid, M. M. (2013). effect of four different commercial diets on growth performance of the cichlid fish, Oreochromis niloticus fingerlings. J. Aquat. Biol. \& Fish., 17 (3): 35 - 46.

Khalil1, N. A.; Khalaf-Allah, H. M. M. and Mousa, M. A. (2011). The effect of maternal thyroxine injection on growth, survival and development of the 
digestive system of Nile tilapia, Oreochromis niloticus, larvae. Advances in Biosci. and Biotech., 2: 320-329.

Kocabatmaz, M. E. and Ekingen, G. (1978). Bestatlisu baligi türünde bazi hematolojik normlar üzerine ön çalismalar. Firat Üniversitesi Veterinerlik Fakültesi Dergisi., 4: 223-232.

Morel, D. W.; Hessler, J.R.; Chisolm, G.M. (1987). Low-density lipoprotein cytotoxicity indeed by free radical peroxidation of lipid . J. Lipid Res., 24:1076.

Nicula, M.; Gergen, I.; Harmanescu, M.; Banatean-Dunea, I.; Marcu, A.; Simiz, E.; Polen, T. and Lunca, M. (2011). Assessing the impact of EDTA chelating effect on some macro- and microminerals in prussian carp (Carassius Gibelio) tissues., Animal Sci. and Biotech., 44 (2):40-44.

Nowack, B. (1996). Behavior of EDTA in groundwater- a study of the surface reactions of EDTA metal complexes. Doctoral thesis, E. T. H. Nr: 11392. Zurich. Switzerlasnd, pp 175.

Ragan, M. A.; Ragan, C. M. and Jensen, A. (1980). Natural chelators in sea water: detoxification of $\mathrm{Zn}^{++}$by brown algal polyphenols. J. Exp. Mar. Biol. Ecol., 44:261-267.

Recker, W. E. (1975). Computation and interpretation of biological statistics of fish populations. Fish. Res. Board Can. Bull., 191, 1-382.

Reitman, S. and Frankel, S. (1957). Determination of transaminase enzymes. American J. Clin. Path., 28: 56.

Rengaswamy, G.; Narmada, S.; Vijayakumar, R. and Abdul-Jaleel, C. (2009). Chelating efficacy of $\mathrm{CaNa}_{2}$ EDTA on nickel-induced toxicity in Cirrhinus mrigala (Ham.) through its effects on glutathione peroxidase, reduced glutathione and lipid peroxidation. C. R. Biologies., 332: 685-696.

Salah El-Deen, M. A; Salah, R. E.; Issa, A. M. and Abo-Hegab, S. (2000). Some metallic altrations in grass carp, Ctenopharyngodon idella, induced by exposure to mercury and zinc. Egypt. J. Aquat. Biol. \& Fish., 4(3):21-43.

Salah El-Deen, M. A.; Sharada, H. M.; Abou El-Ella, S. M. (1996). Some metabolic alteration in grass carp, Ctenopharyngodon idella induced by exposure to cadmium. J. Egypt Ger. Soc. Zool., 21 (A): 441 -457.

Shalaby, A. M. (1997). Biochemical and physiological studies on metal contamination in the common carp (Cyprinus carpio L). Ph. D. Thesis., Fac. Sci., Zagazig Univ., (Benha branch)., 268pp.

Shalaby, A.M. (2003). Effect of edta on reduction of cadmium toxicity on growth, some haematological and biochemical profiles of Nile tilapia (Oreochromis niloticus). American J. Clinical Nutr., 78(2): 274-278.

Shalaby, A. M. (2007). Effect of EDTA on Toxicity Reduction of Cadmium in Relation to Growth, Some Haematological and Biochemical Profiles of Nile Tilapia (Oreochromis niloticus). J. Fisheries and Aqua. Sci., 2 (2): 100-109

Shalaby, A. M.; Ramadan, A. A.; El Gammal, M. A.; El Aganif, E. M. and Ebrahim, M. S. M. (2011). Beneficial using of EDTA to reduce cadmium toxicity and to improve the physiological and biochemical profiles of catfish (Clarias gariepinus). Egypt. J. Aquacult., 1(1): $55-69$.

Singh, N.B. and Sinha, R.N. (1977). Carbohydrates, lipids and protein in the developmental stages of Sitophillus oryzea and Sitophillus grannarius. Ann. Ent. Soc. Am., pp.107: 111.

Sunda, W. and Guillard, R. R. L. (1976). The relationship between cupric ion activity and the toxicity of copper to phytoplankton. J. Mar. Res., 34:511-529.

Svoboda, M (2001). Stress in fish - review. Bul. VURH Vodnany., 37: 69- 191. 
Tahoun, A. M. A. (2007). Studies on some factors affecting the production and reproduction of Nile Tilapia. Ph. D. Thesis, University of Kafr El-sheikh, Egypt.

Tavares-Dias, M. and Silva-Sandrim, E. F. (1998). Influence of anticoagulants and blood storage on hematological values in tambaqui, Colossoma macropomum. Acta. Sci., 20: 151-155.

Tonsy, H. D. and Abdel-Rahman A. S. (2012). Effect of chelating agent EDTA (ethylene diamine tetra acetic acid, disodium salt) as feed additive on controlling heavy metals residues in Sarotherodon galilaeus fish. Egypt. J. Aquat. Biol. \& Fish., Vol. 16, No. 1: 145 - 156.

Tsadik, G. G. and Bar, A. N. (2007). Effects of feeding, stocking density and waterflow rate on fecundity, spawning frequency and egg quality of Nile Tilapia, Oreochromis niloticus (L.). Aquacult., 272: 380- 388.

Vaara, M. (1992). Agents that increase the permeability of the outer membrane. Microbiol. Rev., 56: 395-411.

Venkat, H. K.; Sahu, N. P. And Jain, K. K. (2004). Effect of feeding lactobacillusbased probiotics on the gut microflora, growth and survival of Macrobacteriumresenbergii (de man). Aqua. Res., 35: 501 - 507.

Yamawaki, K.; Hashimoto, W.; Fujii, K.; Koyama, J.; Ikeda, Y. and Ozaki, H. (1986). Hematological changes in carp exposed to low cadmium concentration . Bull of the Japanese. Soc. Sci. Fish., 59 (3):459- 466.

Zaghloul, K. H. (1997). Studies on the effect of water pollution along different sites of the River Nile on the survival and production of some fresh water fishes. Ph.D. Thesis, Fac. Sci. Cairo Univ. Egypt. 


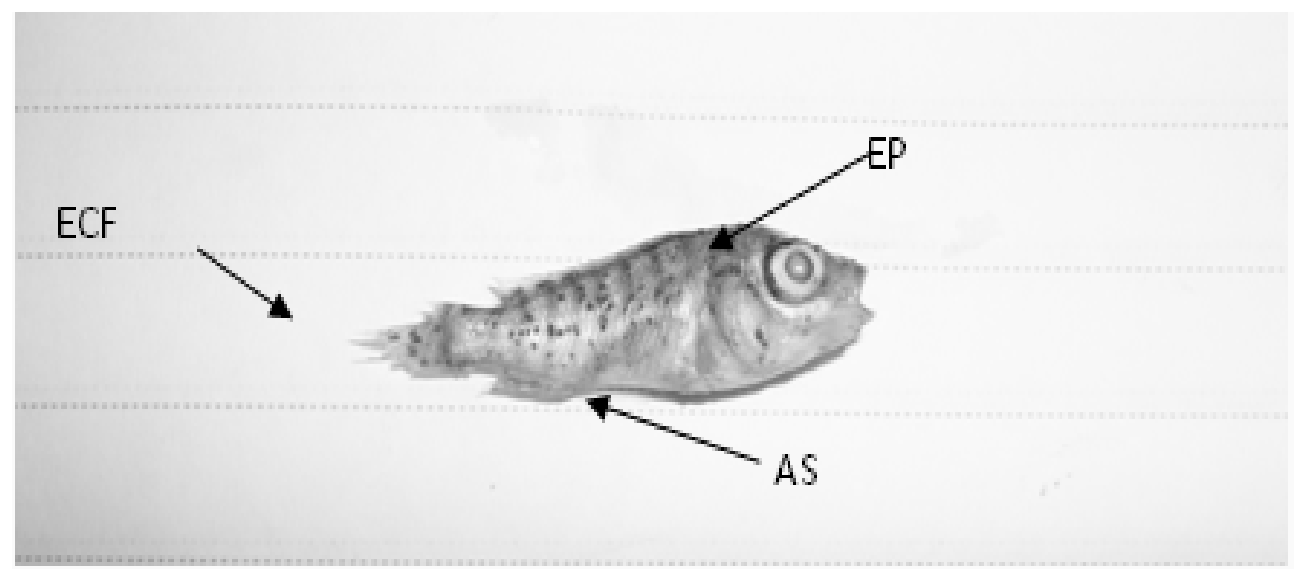

Fig. 2: The external mortality signs of control showing erosion of caudal fin (ECF), exophthalmos (EP) and abdomen swelling (AS).

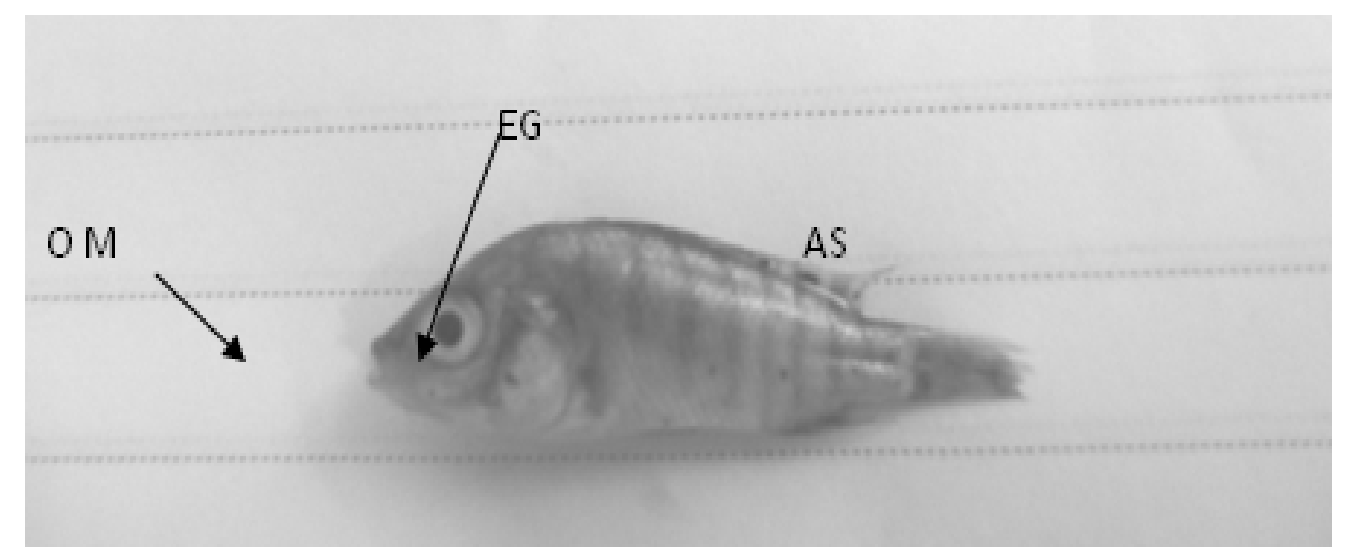

Fig. 3: The external mortality signs of treated fish showing the enlargement in gills (EG) associated with open mouth (OM). 


\section{ARABIC SUMMARY}

تأثير تركيزات مختلفة من مادة الإيثليلين ثنائى الأمين رباعي حمض الخليك (إيدتا) على النمو، الأداء

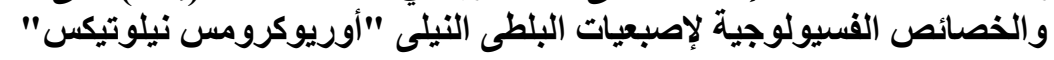

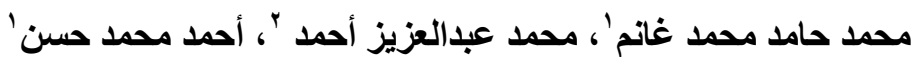

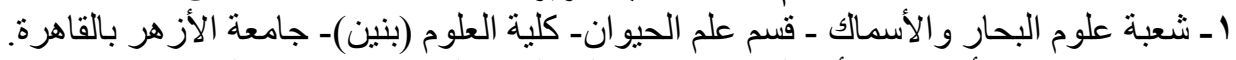

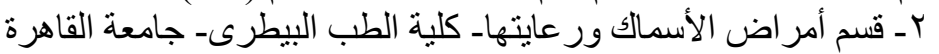

من أولي المشاكل الخطيرة والهامة في كثير من دول العالم هي نقص البروتين الحيواني اللازم اللغذاء

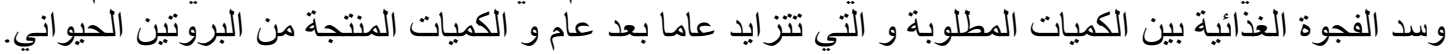

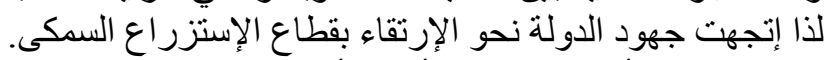

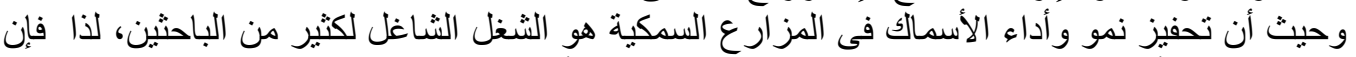

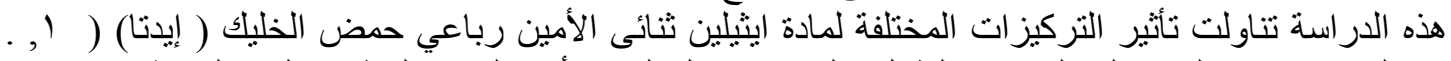

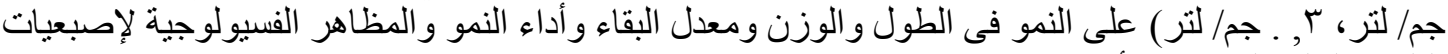

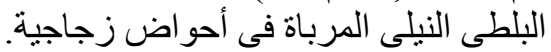

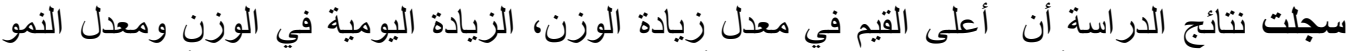

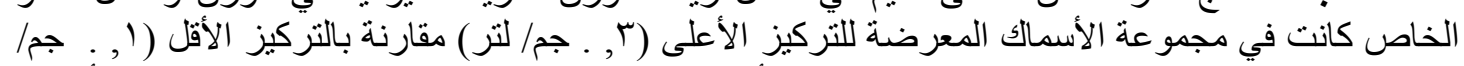

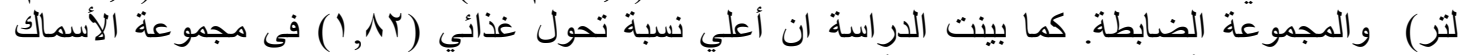

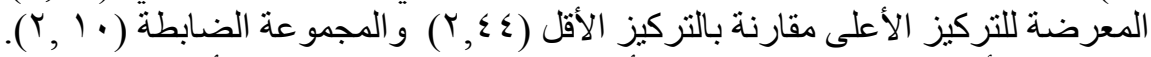

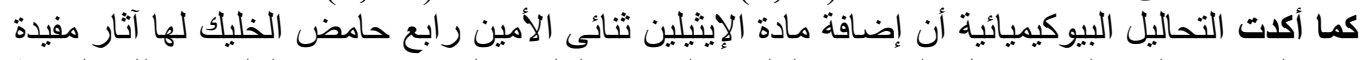

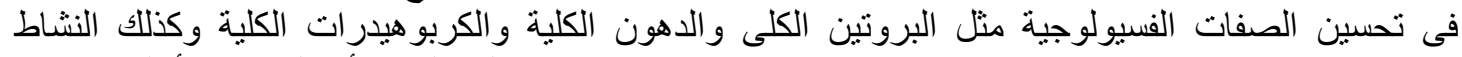

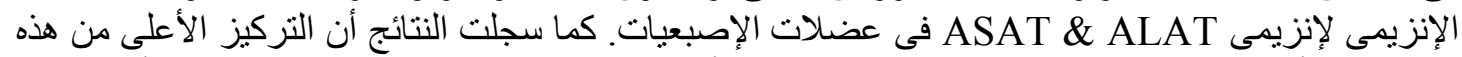

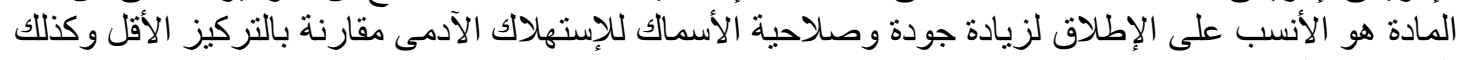

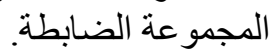

وتثثير نتائج هذا البحث إلي أفضلية إستخدام مادة الإثليلين ثنائى الأمين رباعي حمض الخئل الخليك (إيدتا) عند

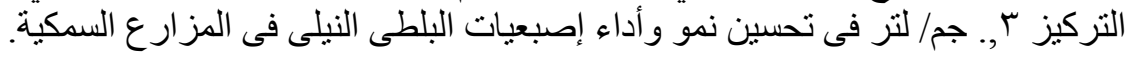

